This article was downloaded by: [New York University] On: 13 August 2013, At: 12:36

Publisher: Routledge

Informa Ltd Registered in England and Wales Registered Number: 1072954 Registered office: Mortimer House, 37-41 Mortimer Street, London W1T 3J H, UK

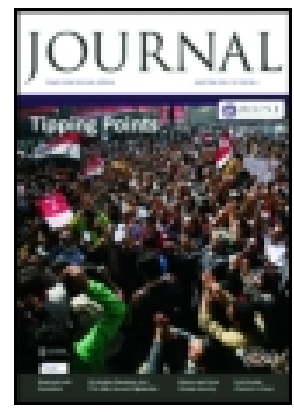

Royal United Services Institution. J ournal

Publication details, including instructions for authors and subscription information: http:// www. tandfonline.com/ loi/rusi 19

\title{
On a Colonial Naval Volunteer Force
}

Thomas Brassey Esq., M.P.

Published online: 11 Sep 2009.

To cite this article: Thomas Brassey Esq. , M.P. (1878) On a Colonial Naval Volunteer Force, Royal United Services Institution. J ournal, 22:96, 641-660, DOI: 10.1080/03071847809418237

To link to this article: http://

dx. doi.org/ 10.1080/03071847809418237

\section{PLEASE SCROLL DOWN FOR ARTICLE}

Taylor \& Francis makes every effort to ensure the accuracy of all the information (the "Content") contained in the publications on our platform. However, Taylor \& Francis, our agents, and our licensors make no representations or warranties whatsoever as to the accuracy, completeness, or suitability for any purpose of the Content. Any opinions and views expressed in this publication are the opinions and views of the authors, and are not the views of or endorsed by Taylor $\&$ Francis. The accuracy of the Content 
should not be relied upon and should be independently verified with primary sources of information. Taylor and Francis shall not be liable for any losses, actions, claims, proceedings, demands, costs, expenses, damages, and other liabilities whatsoever or howsoever caused arising directly or indirectly in connection with, in relation to or arising out of the use of the Content.

This article may be used for research, teaching, and private study purposes. Any substantial or systematic reproduction, redistribution, reselling, loan, sub-licensing, systematic supply, or distribution in any form to anyone is expressly forbidden. Terms \& Conditions of access and use $\cong$ can be found at http://www.tandfonline.com/page/termsand-conditions 


\section{LECTURE.}

Fridas, MIay 17th, 1878.

ADIIRAL A. P. RYDER in the Chair.

\section{ON A COLONIAL NAVAL VOLUNTEER FORCE.}

\section{By Trouras Brasser, Esq., MI.P., Lieuteuant Commanding Royal Naral Artillery Volunteers.}

IT is not suprising that the idea of organizing a Colonial Naval Reserve should have been deferred to the present time. The growth of our Colonial Empire has been so rapid that the resources out of which such a force could be created have only lately been at our disposal.

It has been remarked by Mr. Wilson, in his recent rolume on tho resources of modern countries, that none of the colonies were of great promiso before 1845. Canada languished; New South TVales-then including Victoria and Queensland-was a feeblo settlement, still troubled by a residuum of transported criminals; the Cape of Good Hope was almost Dutch. The total English popnlation of the whole of our foreign possessions did not, in 1850, exceed 2,000,000. The population of these colonies has at least quadrupled in thirty jears, and in some cases is now tenfold what it was in 1845 .

Visitors to the Exhibition now being held in Paris will seo abundant and gratifying proofs of the marrellous derelopment of our colonies, and of their ability to provide adequate means of self-defence. The Australian governments have wisely embraced the opportunity of showing to the world their varied and valuable products. From Now South WVales we hare copper, silver, lead, marble, tin, slate, and opals; wine-including all the varieties of the French and German vineFards-tobacco, and, perhaps most important of all, wool. From Western Australia we find leather, timber, silk, coal, lead, and wines. Victoria, which boasts of 800 trees and flowering shrubs, exhibits also coal, wines, and cloth manufactures. She reminds us, by means of pjramidal models, of the value of her productions of gold, and of the exceptional good fortune of certain adrenturers. From the Cross Ref Arine $f 1,000,000$ worth, from the Long Tunnel 221,262 ounces, from the Port Philip Company's workings to the ralue of $£ 1,500,000$ have been extracted. 
Queensland exhibits malachite, gold, copper, cinnabar, chrome, iron, plumbago, and antimony, sugar, coffee, wheat, maize, tobacco, silk, and wool. The commercial and agricultural development of the colony is set forth in the following figures:-

In 1876 the total value of the exports amonnted to $£ 3,875,000$, including -

\begin{tabular}{|c|c|c|c|}
\hline Wo & & & $\mathfrak{e 1 , 4 4 9 , 5 7 6}$ \\
\hline Hide & $\theta$ & .• & 79,612 \\
\hline Cattlo & $\because \quad \cdots$ & & 157,772 \\
\hline
\end{tabular}

The valne of the imports in the same year was $£ 3,126,000$.

Queensland has a population of 200,000 .

The live stock depastured includes-

$\begin{array}{llllr}\text { Horses } & \ldots & \ldots & \ldots & 130,289 \\ \text { Cattle } & \ldots & \ldots & \ldots & 1,985,807 \\ \text { Sheep } & . & \ldots & \ldots & 7,241,810 \\ \text { Pigs } & . & \ldots & . & 53,455\end{array}$

Lastly, South Australin exhibits copper, tin, wines, timber, leather, wool, and tobacco. With such a collection before us, wo are justified in forming the brightest hopes for the future prosperity of the great Anglo-Saxon communities in the Antipodes. The page of their history is short, but they are a vigorons and energetic people, eager to ombrace every opportunity afforded by a bountifal nature, and labour. ing raliantly in the spirit of their well-chosen motto, "Adrance "Australia."

The time seems now to have arrived when the colonies should be reminded of their obligations to provido for their own self-defence, and of their duty to take a part in those naval and military preparntions, the cost of which should be borno in due proportions by the whole Empire.

The necessity for the organization of a Naval Reservo for the defence of the colonies has been recognised by many lecturers, who have preceded me in the theatre of the Royal United Service Institu. tion. The brothers Colomb hare been among the foremost in urging the need of such a force. They have shown what are the strategical points which are of the most vital importance to the integrity of the British Empire, and have carnestly recommended the appointment of a Royal Commission to examine the subject. Nothing, however, has been done, and wo find ourselres at the present moment contem. plating the possibility of war, and utterly unprepared with the menns of defending the important outlying members of the Empire by those local forces, which might so easily hare been organized. Readers of the papers published in tho "Nineteenth Century" will remember the imaginary bat very forcible description recently giren by Sir Garnct Wolseley of a Russian squadron performing a cruise of circumnarigation in time of war, arriving off all our most raluable settlements, and winning a series of inglorious triumphs by levying black-mail on rich seaports, which could offer no resistance. It would per- 
haps be found more difficult to carry out such a series of operations, than to describe them with the ready pen, which Sir Garnet so well knows how to use; but the bare conception of such a stato of things onght to be unendurable, alike to the people of the mothercountry and of her dependencies.

The policy of encouraging such a movement having been accepted, there can be no practical difficulty in raising a Naval Reserve in the colonies. If it bo intended to provide the means of manning seagoing ships, the Naval Reserve which has been formed for the defence of the mother-country presents a model for imitation. If coast and harbour defence alone is attempted, the system of organization adopted for the Rojal Naval Artillery Tolunteers may be followed with adrantage.

In considering a project for a Colonial Naral Reserve, it is essential to determine, in limine, to what extent the direct intervention of the Imperial Government will be required. Among a certain school of politicians, it will be considered that local defence is a task which must be left entirely to the Colonial Gorernments. They think that the colonies are quite able to take care of themselves; that, man for man, the colonists are better off than the population of the mothercountry; that it is the dnty of our statesmen to rear up young and vigorous communities in habits of self-defence, and to bring home to their people a sense of their obligation to make sacrifices for public objects, and to bear their proportionate share with the mother-country of the burdens of military preparations.

Another school of politicians is in favour of a closer connection with the colonies. They are anxions to promoto a federal union of all the members of the British Empire: They wish to arrive at a mutual agrecment on all questions of tariffs; and, with a view to concerted action in Imperial questions, they are in farour of giving to the colonies representatives who should sit in the great council of the Empire at its seat of Government. In consideration of the protection afforded by the flect; they are prepared to recommend a contribution from the colonies to the naral expenditure of the country. In these views I concur, and I see additional evidences of their truth in the most recent incidents in our political experience. It is rarely possible for this country, under a popular representative Gorernment, to purste a satisfactory course in its relations with forcign countries. The greater numher of those who take a lirely interest in public business concern them. selves rather with domestic questions than with foreign policy. Being without knowledge, they arrive at hasty conclusions, and every new incident that occurs produces a corresponding change in their opinions. Hence it is that our foreign policy is inconsistent and uncertain ; that wo disappoint allies in whom we hare raised expectations; and make sacrifices for unattainable or unworthy objects.

The Eastern Question once disposed of, it is my carnest hope that the attention of British statesmen-may be directed rather to the object of drawing the colonies and the mother-country more closely together, than to continental affairs.

In our relations with other nationalities we excite jealousy by roL. XxII. 
our prosperity. Although singularly unselfish and unaggressire, our country is not greatly loved abroad. On the other land, old England, as their mother-conntry, still retains the warm affection of her colonies. Our Gorernment may show a chilly indifference to their concerns, but England is still the "home" of all English-speaking people; and the identity of religion, history, laws, and literature, unites together crery member of the family by bonds more enduring than the protocols and trenties, howerer raluable they may be, which are negotiated with foreign nations.

The arguments in farour of a cordial co-operation of the United Kingdom with the colonies in measures of mutual self-defence have been conclusirely stated by several able writers in recent periodicals. I may specially refer to Captain Colomb, Sir Julins Vogel, and the author of a papor on England and her Colonies, which appeared in "Fraser's Magazine," in January. Wo are reminded, in the papers to which I refer, of the value of the colonies to the mother-country, for the ineritable dovolopment of the British population, and as the main source of our maritime prosperity. Whilo foreign countries are steadily determined to exclude British industries from the markets over which they exercise control, the ralue of the colonial trado becomes increasingly manifest : and, while we derive these advantages from our rast colonial connection, it is obrious that, in proportion to their own prosperity, the colonies are bound to talse their share in defending the Empire. It is to bo regretted that these obligations were not more strictly defined at the time when the privilege of self-gorernment was conceded.

In his speech at the Crjstal Palace, in 1872, Lord Beaconsficld said :- "Self-gorernment, when it was conceded, ought, in my opinion, " to have been conceded as part of a great policy of Imperial consolida" tion. It ought to have been accompanied by a military code, which " should have previously defined the means and responsibilities by "which the colonies shonld have been defended, and by which, if " necessary, this country should call for aid from the colonies them"selves. In my opinion, no minister in this conntry will do his duty, " who neglects an opportunity of resuscitating as much as possiblo our "Colonial. Empire, and of responding to those distant sympathies " which may become the source of incalculable strength and happiness "to this land."

From an Imperial point of view, the best defence of the colonies consists in a powerfol navy; and it is because the naval service is constituted in part for the defence of the colonies that we may reason. ably claim from all onr dependencies contribations in equitablo proportions, to be mutually and amicably determined, towards tho naval expenditare of the country.

The latest tables, showing the progress of British mercantile shipping, give the total tonnage of the mercantile nary of the British Empire at 8,133,837 tons, and the tonnage of the United Kingdom only at $6,336,360$ tons. The difference between these amounts $(1,800,000$ tons) represents a total tonnago for the colonies which is. little short of the combined tonnage of the French and German 
Empires. It must be evident that the owners of such a large tonnage will be quite able to contribute their share of the cost of defending the harbours from which they trade.

It has been suggested by Captain Colomb, R.Mr.A., that one of the home dockyards-Pembroke, for example-might be closed, and the staff transferred to a dockyard which should be established at Sydney or DIelbourne. Captain Colomb urges that, with our remaining dock. rards, and the boundless resources of our private trade, wo should be abundantly able to provide for the construction of new ships, and for the repairs of the Nary, cren in times of the most pressing emergency; while, on the other hand, the growing importance of the Russian navy in the Pacific, the extension of British trade over most of the islands in that vast ocean, and the great distance which separates our Australian territories from the mother-conntry, mako it highly desirable to establish a dockyard in that part of the world. It is to be presumed that some contribution rould be obtained from the local governments towards the expenses of such a dockyard, if established in their midst. The facilities which it would afford to the mercantilo marine would present an additional inducement to the colonies to make a contribution towards its maintenance.

The colonial gorernments have already begun to consider tho question of local defence, and in one or tro instances they have provided low free-board ironclad turret-ships for that purpose. Victoria has lately roted a sum of $\$ 350,000$, together with an annual outlay of

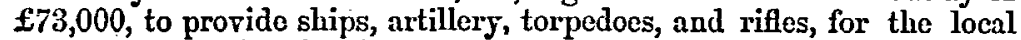
defence. New Sonth Wales has roted a like sum for the same object. The colony has formed a Volunteer Naral Brigade of $250 \mathrm{men}$, tho annual expenditure on this little force boing $£ 3,916$. In the Canadian Dominion, a committee appointed by the Rogal Halifax Yacht Club, in a report dated 14th $\Lambda$ pril, 1873 , strongly recommend the organization of a Naral Reserve, a Coast Guard to protect property in the erent of shipwreck, and a Lifeboat Institution.

It mny be assumed that the Colonial Gorernments would be fully prepared to bear their share of the expenditure required for any complete scheme of Imperial defenco by naval means; we may pass on thereforo to consider what hind of force would bo most useful for colonial service.

It has been already observed that the most effectire means of defending the larger ports rould consist in ironclads or turret vessels rather than in forts. Captain Colomb, R.N., has urged in his Prize Essay that the main object of our naval organization consists in the maintenance of our communications by sea, and that our coalingstations abroad are the principal strategical positions which it is essential to guard. He argues that this object will be best attained by tho maintenance of an adequate sea-going fleet, charged with two great defensire functions :-(1) that of keeping the enemy in his own ports, (2) that of keeping open the great sea-routes to and from the heart of the' Empire. He considers t'at this duty can only va performed by sea-going ressels, and that the building of porrerful ships; which are not fully sea-going, and which are more or less incapable of $2 \times 2$ 
maintaining the ocenn communications of the Empire can only be justified on the assumption that the chief danger to be apprehended lies in a successful attack on our harbours.

But if, he says, our enemies are to career at will across our lines of communication, while we gaard their terminations at head. quarters, what will be left us to guard $?$ Ho puts much faith in the sea-going flect resting on the naval station as a protectivo force, and condemns with steady design the idea of the harbour-defence ship. Such ressels are every whit as likely to be withdrawn as the sea-going ship, when they are wanted; and the only result is that you build a bad sen-going ship, when, had you never considered harbour-deience, sou would have built a good one.

Captain Colomb throws the local home and colonial harbour-defence entirely on forts, and the stationary and locomotive torpedoes. The supplemental local harbour-defence corps is to consist of volunteer torpedo men, whose functions will be of a nature peculiarly adapted to the superior education and undoubted skill and daring of the men who wonld be enrolled in such bodies.

This view is confirmed by the recent report of Admiral Plillimore on the conduct and efficioncy of the Royal Naral Artillery Volunteers, dated 15th March, 1878.

The opinion of my predecessor on the Rojal Naral Artillery Voluntecrs is giren at page 7 of his Confidential Report, on quitting office, dated 18th October, 1676:-

"Tluat they would be useful in the erent of war, in the defence of the estuaries, while in peace they serre as a connecting link between the Tolunteer morement and the Royal Nary."

Both at London and Lirerpool the condition of the Brigado is excellent. Tho Folunteers drill with celerity and precision, and are estremely zealous. They cheerfully conform to discipline, and are desirous of improring themselres in erery way when embarked for their annual drill.

In some places thes might supply the place of the Constguard temporarily, if that force should bo suddenly embarked.

Thes might furnish guards at rendezrous and places of embarkation to preserre order. MIany of them hare become expert artillerists.

I think the morement assists in making the Naral Scrrice belter nppreciated and nnderstood at certain places, and consequently increases the popularity of the Nary generally, which, if more esamen were required for ships of war, might be of grest ralue in facilitating fresh catries.

In my judgment, Captain Colomb is the advocate of a wiso polic5. The Imperial and Coloninl Governments should combine to create a fleet of sea-going ships, which should be kept in reserve in the harbours on the Australian station. Torpedoes and torpedo-boats should be prorided for harbour defence. The Colonial Governments should man the sen-going ships, stationed in their own harbours, with their Naval Reserres, and they should provide the personnel necessary for harbour defence by the organization of corps of Naval Artillery Volunteers, after the model of those which have been successfully established in London and Lirerpool.

The number of sca-going ships and torpedo-boats, and the forces of Naral Reserres and Naval Artillery Volunteers, which would be necessary to man them, is a subject worthy of mature examination by 
a Royal Commission. Such a Conmission should include, not ouly officers of acknowledged capability to deal with technical questions, but representatives, who should be authorised to express the views of the colonists, with reference to the proportions in which they would be prepared to contribate to the expense.

I wish to insist emphatically on the importance of the work which would derolve on such a Commission. We cannot conceal from the world the wealth accumulated in the colonial capitals, all of which lie on the sea-board. Their inhabitants possess all the spirit and resources necessary to repel an attack, but theso places are at present dofenceless. Flonting and stationnry defences cannot be designed, a Naval Reservo or Militia cannot be organized, without naval and military advice. The colonies having no body of officers to assist them in such a task, it is for the mother-country to take the initiative in the disclarge of the urgent Imperial duty of preparing a scheme for the mutual self-defence of all the dependencies of the Empire.

I am not competent to enter into the details of such a scheme as the Royal Commission which I recommend would be enabled to prepare. A degree of local and professional knowledge, which I cannot pretend to possess, and which, indeed, cannot bo combined in any individual, would be required in the preparation of a satisfactory plan. As an example of what might be done, I will, however, renture to refer to some notes which I made on the formation of a Naval Reserve in Canada, after visiting the ports in the Gulf of St. Lawrence in 1872 .

It is believed that in the Canadian Dominion there are not less than 87,000 seafaring men. In 1872 , about 1,000 decked. ressels, and 17,000 open boats, manned by 42,000 men, were employed. On December 31st, 1876, the Canadian Dominion possessed 6,952 ressels, of $1,205,565$ tons. During the year 1876,480 new ressels, of 151,012 tons, were built in the Dominion. The value of the fish exported from Canada in the same jear amounted to $£ 1,000,000$. The value of the exports of the same class from Newfoundland in 1875 was $£ 1,340,000$.

It is stated in the annual report of Gorernor Hill, for 1872, that about 10,000 men are engaged in the senl fishery of Newfoundland, and that this number includes almost erery available able-bodied man on the island. The total male population, it should be added, is 75,000 .

The rigorous climate of Canada and Newfoundland, throughout their long winter season, makes it impossible for fishermen to follow their regular rocation. The long interval of enforced idloness during winter would afford an admirable opportunity for regular attendance at drill, without interfering with other lucrative employment. $A$ vigorous effort should be made to enrol theso colonial fishermen in the Taval Reserre of the British Empire. They are thoroughly inured to the hardships of the sea by the severe weather, which frequently prevails on their native shore. No subjects of the British Crown are more logal and deroted. There would be no difficulty in giving to the fishermen of Trewfoundland and the maritime provinces of the Cauadian Dominion an opportunity of embarking for their annual drill at a jort 
easily accessible from their own homes. A ressel should be commissioned specially for the purpose of training seamen, who hare joined the Naral Reserve from Newfoundland, from the ports in the Gulf of St. Lawrence, and from Quebec, Montreal, and other places on the great river. The ressel should be of the corvette class, having a covered deck, in which the battery of guns would be placed. In such $a$ ressel the drills might be carried on with regularity in the most serere weather. The drill-ship would be stationed during mid-winter at St. John's. The harbour is admirably sheltered and a large population of fishermen is congregated in the town and its vicinity. During a portion of the winter the drill-ship should be moved to other points on the const where the fishermen are settled in large numbers. Thus the members of the Colonial Naral Reserre would have an opportunity of going through the annual course of drill, withont being exposed to the hardship of a long sea-roynge to St. Jobn's in their small fishing boats in mid-winter. Along tho consts of Nowfoundland there are numerous admirably sheltered harbours, which are rarely frozen up. An anchorago might be selected for the training-ship both in Planentia Bay and in Trinity Bay, perfectly secure, and easily accessible to the large numbers of British seafaring men dispersed along those distant shores. As the spring approached, and the narigation was opened in the Gulf of St. Lawrence, the slip could proceed from harbour to harbour along the southern shores of the Gulf. At Sydncy, Charlottetown, and Gaspe, many seamen could bo enrolled for the national reserre. It should be arranged that the drill-ship should risit the harbours mentioned sufficiently carly in the season to enable the seamen sailing from those ports to go througl their annual drills, before the navigation of the St. Lawrence was fally open. The reserre men might thus have the opportunity of attending on board the trainingship, withont suffering the serious inconrenience which would be felt if they were taken from their employment afloat in the season of open narigation. Another similar training-ship shoald be stationed at Halifax, which should visit the numerous harbours on the coast of Nora Scotia and in the Bay of Fundy, in the winter season, when multitudes of fishermen are compelled to remain on shore in consequence of the inclemency of the weather.

We hare not neglected to arail ourselres of the serrices of our colouial population for the purpose of increasing our military resources. We hare enrolled large bodies of men belonging to races distinct from our own. There can be no sufficient reason for neglecting to recruit for the Nary among the rast numbers of lojal Englishmen, who animated by a splendid spirit of enterprise and adrenture, have settled on the extensire coasts of our Canadian Dominion.

In a lecture delirered at the Rojal Colonial Institute, on the 4th Februar, 1873, MI. Bourniot, a member of the Canadian Senate, remarked that, "In the men that sail the fishing fleets of Canada, we "sce the elements of a very powerful marine, which will be found in" raluable in times of national danger. It may be estimated that the "total strength which the fisherics cmploy throughout all British North "America is composed of some 70,000 men." M. Bonrniot was of 
opinion that there was no reason why training ships, supported by the local gorernments, should not be started in the colonies, if the system were found to work well in the United Kingdom.

The policy recommended seems to be in consonance with the views expressed by Lord Elgin, who, when Governor-General of Canada, argued with so much force on the adrantages to England and her colonies of an intimate union between them. "Is the Queen of "England," he wrote, "to be the Sorercign of an Empire, growing, " expanding, strengthening itself from age to age, striking its roots " into fresh enrth, and drawing new supplies of ritality from rirgin "soils? Or is she to be, for all essential purposes of might and power, "Monarch of Great Britain and Ireland merely ?"

The organization of a Naral Reserre in our North American Colonies is not only to be desired as a means of adding to our naral strength for Imperial purposes, but also for defending the colonies themselves. All our colonies, including India, should hare a defensive force of their own. Organization beforeland is essential to saccess in war. By the bestowal of infinite pains on her military organization, Prnssia, which seemed for erer fallen after the battle of Jena, turned the tide of fortune in 1815, and, after the campaigns of 1866 and 1870 , has become the greatest power of Central Europe.

It is one of the great recommendations of the scheme which I have adrocated on this occasion, that it nced not involre the country in a lavish expenditure. It is well to prepare in advance plans of earthworks, to be thrown up when required, and to organize corps of naval volnnteers. It does not follow that we should andertake the construction of the extraragant fortresses which surround our arsenals at home, or withdraw a single man from the well-rewarded labour-market of the colonies. To build fleets and forts, and to maintain armies in every dependency of the Crown, would be an crhausting and an unnecessary effort. I remember, and approre, the language held by Sir Robert Peel in 1850, when he said: "I beliere that in time of pence we must by our re" trenchment consent to incur some risk. I renture to say that if you " choose to have all the garrisous of all your colonial possessions in a ss complete state, and to have all your fortifications sceure from attack, " no amount of annual expenditure will be sufficient to accomplish jour " object."

Since the date of Sir Robert Peel's specch, that noble Volnnteer morenent, one of the most honournble features in the recent history of this country, has been originated. A quarter of a century ago, the voluntary submission to drill and discipline of large masses of men, in numbers for exceeding those enrolled in the regular Army, was not anticipated by British statesmen. By the extension of the Voluntecr movement, garrisons can be maintained in the largest fortresses and in the most distant outposts, without adding in any appreciable degree to the charges on the Imperial and Colonial revenues.

The mother-countr'y could rendily furnish a staff of officers and instructors for the purpose of training the Colonial Naval Reserves. The number of officers required must depend on the strength of the 
force which it is deemed expedient to raise. In whaterer numbers they may be wanted, they can be supplied from the ranks of those who have retired from the active list, or who are, for the time being, on half-pay. The presence of a body of naval Officers in our colonies will form a valuable link with the United Kingdom.

They will carry with them the spirit of discipline and derotion to their country, which they have acquired from service in the Nary, and they will help to keep alive its illustrions traditions in those young communities, in which it is so important to create a high tone of morality and conduct. The example of her great men is the most raluable inheritance of a nation, and in the career of many of our sea officers the highest moral excellence has been combined with dauntless bravery and skilful seamanship.

Readers of naval story mill be familiar with the fine passages in which Southey concludes his biography of Lord Nelson. He tells us how, on the sunny morning of the 21st October, 1805, as the British flect was bearing down on the formidable array of ships under Villeneure, Nelson withdrew to his cabin, and, looking for death with almost as sure an expectation as for victory, piously discharged his devotional duties. You know with what calm cournge shortly afterwards be entered into battle, and with what conduct and valour our officers and men followed their illustrious chief to victory. The battle of Trafalgar, though considered by Southey as the most signal success that erer was achieved upon the seas, was dearly bought by the death of Nelson; and jet, as his biographer most truly says, "Ho cannot be "said to have fallen prematurely, whose work was done; nor ought he " to bo lamented, who died so full of honours, and at tho height of " human famo. The most triumphant death is that of the martyr; the " most anful that of the martyred patriot: the most splendid that of "the hero in the hour of victory: and if the chariot and the horses of " fire had been ronchsafed for Nelsoñ's translation, he could scarcely " have departed in a brighter blaze of glory. He has left us, not indeed " his mantle of inspiration, but a name and an example, which are at "this moment inspiring thousands of the youth of Englnnd, a name "which is our pride, and an example which will continue to be our " shield and our strength."

That the nary of our own time contains many brave men, prepared to serve their Queen and country in the spirit which animated Lord Nelson, we cannot doubt. You remember how the gallant Burgoyne refused to enter the boat in which the sole survivors of the crew of the "Captain" were saved. Humanity to the savage, and fortitude in death wero conspicuously illustrated in the closing hours of Captain Goodenough. But the occasions which brought out the high qualities of Lord Nelson are happily rare. The annals of a nation must be long, in order to furnish many examples equally illustrious. Our share in the honour which belongs to the descendants of such men is a privilege of high valne; and it will surely be one of the strongest induccments to the formation of a Colonial Naval Reserve, that a link will thus be created with a navy possessing the splendid traditions which belong to the British service. 
Captain Crpriax Bridge, R.N.: Lest it should be supposed that I haro risen too soon, and not waited for other Officers of greater experience, and who haro giren more attention to this subject than mysclf, I will, with Jour permission, just mention in a few words why $I$ take such an interest in this question. In the firat place, I take an interest that I beliere erery naral Offeer must take; in the second place, $I$ take an interest that I think orery colonist (I myself haring been born and lired in a colony for some rears) ought to take in it; and, in the next place, I take epecial interest in it as having taken some part in trying to direct the attention of my brother Offeers and the pnblic at large to the great question of raising a rolunteer foree which might be to the Nary what tho great Rifle and Artillery Voluntecr force has been to the Army. For these three reasons I hare, perhaps, been induced to pay more attention to this subject than many people are inclined to think it deserres. In my opinion, no subject that could be brought before any assembly of Englishmen, whether in the mother country or the colonies, is more worthy of attention than this. As MIr. Brassey has rery tell told us, in the ablo and interesting paper which he has just finished, the rery life of the Empire depends upon thosc relations which have been maintained with many of our great colonial dependencies. It hus been my good fortune to risit crery great group of colonies, with the cxception of those in South Africa, beginning at Vancourer's Island and ending in Australia, so that I hare a somerhat intimate personal knowledge of the condition of many of them. Of the great colony of Canada I am only acquainted with the maritime prorinces; of Canada proper, the only places I hare erer risited are Gaspd and Paspebiac; as to Nora Scotia, Newfoundland, and New Brunswick, almost erery part of their coasts I know well. To show hon feasible it has been thought in the Dominion of Canada, cren some years before the Confederation, to establish a naral force of their own, there was in existence at Halifax, certainly as far back as 1865 , a naral volunteer force. When I became aware that it was in existcnce, mj stay at IIalifar was too short, and my occupations too numerous, to enable me to make many inquiries concerning it. I did see some of the Officers and men in uniform, but I understood it ras more npon a land basis than a sea basis. The Offeers had military titles, and it was intended that they should be employed in time of $\mathrm{mar}$ chielly in defending batteries on shore. This is not, of course, what has been aimed at in the proposals Mr. Brassey has made this afternoon; but still I think it does show that, eren at that period, they were willing to take some steps towards forming such a forco as has been proposed. With regard to the docking facilities in Australia, there must be maus Officers who hare serred in Australia, much later than I hare; but as far back as 1850 , the ship to which $I$ belonged, of orer 1,400 or 1,500 tons, as we then counted them, was docked at a rery large loek at Cockatoo Island, abore SydnoJ, which eren at that time was rers much larger than was necessary to take in a ship of her size, and had preriously taken in an dustrian frigate. The island was entirely giren up to workshops and such places as are required in a naral fard; and I should imagine, with a rery small expenditure of mones, and in a rery short time, it mould hare been made, and probably is now Inade, a rery suitable and useful naral arsenal. I should, therefore, be rery sorry to see the proposal carried out which Captain Colomb has made, and Mr. Brassey npprored, to close one of our dockjards to open up others, because I do not think it is necessary. There mas ono point to which Mr. Brassey did not allude, which ho mentioned as supplementing his proposal, and that is, he did not draw our atten. tion-it could not hare escaped his notice, becauso he has recently been to those parts himself-but he did not consider it necessary to draw attention to the fact, that in the Indian Empire we hare a rery large nautical population. I do not mean to put them upon anything like the same footing as the colonists; but that thes are good seamen, and fit to go anjwhere, has been slown by the manner in which thes hare altogether taken the place of European scamen on the splendid Peninsular and Oriental steamers, not to mention others. It would be posisile to so organize a force of these men, that they might set free a rery large number of she seamen belouging to Her Majesty's Serrice at present engaged in special cmploy: ment, which, during war, could be performed by men of the description of which I hare spoken, and rould enable the Europeans who now are employel in them to take part in the more important operations of war. There are also, I beliere, con- 
siderable naral establishments there; at Bombay, I understand, the dochyard is a rery large one. Mentioning that, reminds me of the unfortunate fact, that the Indian Nary was abolished; we are now feeling the want of it. In JIr. Brasser's paper, he of course alluded to a subject mhich, if not obriously, is rery intimately connected with one to which he mas rirtually addressing himself, and that is the defence of our ocem commerec. Of course, this question of raising a roluntcer naral force in the colonies is solely with $n$ riew to defending our commerce. It seems to mo there is a great amount of unneccssary alarm. No country has erer had so great an occan commerce as wo hare, and no country has erer been in a position so thoroughly well able to defend it. All the arguments drawn from the case of the "Alabama," or the history of the war between the Northern and Southern States, when the American flag was driren from the ocean bJ one or two fast cruizers, arc absolutely inapplicable to the condition of affairs at present. The Ameriean flag flew on sailing ships almost exclusircly, and the cruizers which went against those slips, and erentually swept them of the scas, were steamers. A glance at the chart (on the rall) will sliow that it is marked with numerous lincs, which lines, going from port to port, mark out the great highwars upon which the occan commerce of the world chiefly passes. Almost without an exception, erery one of the most important of those lines begins and ends at or passes through some British possession. There is one great gap, I admit, in the system of defence supplied by our foreign possessions; that is the line which, we will say, begins at Vancourer's Island and ends at the south of South America and the Straits of Magellan. It is true that that line is flanked entirely by forcign countries, and we hare no stations within thoso limits, mhich must be some 6,000 or 7,000 miles apart, where we can post a defensire squadron, or, what is still more important, for a defensire squadron, obtain supplics. But me ought to recollect we hold both ends of the line in our own hands. We hold Tancourer's Island, and we hold almost entire command of the Straits of MIngellan in the Falkland Islands. If, therefore, wo maintain the positions we hare got, and by so doing prevent the only eruizers that can bo sent abroad by any enemy, Russia for instance, obtaining supplies of coal, I do not sce what we hare to fear from vessels cmployed as the "Alabama" was employed. Our commerce at present is carricd on to a much greater extenl than erer before by stcam ressels. Those stcam ressels would find almost along the whole of their route always friendly coaling stations where they could obtain supplies of fuel. But no other country would be in the same position, or scarcely any other country. Consequently, I do not think there is much danger, cseept perhaps at the rery outset of war, when cruizers would start with full supplies on board, which they would aftermards find rerJ great difficulty in replenishing. I do not think, except at the outset of war, much danger need be anticipated ; and probably the inereased "risk," in case of war with Russia at this moment, would bo no more than a rery small addition to the insurance already paid. It therefore shows how extremely necessary it is that we should defend and hold these plaees, and keep them entirely sccure against attack. Therefore $I$ say it would bo moro advisable to turn our attention to establishing a naral rolunteer force which should be upon the spot, and should keep those places in our liands, and present them falling into the hands of the enemy, than to drawing upon it to man cruizers and keep open highriays, a sexrice which I think would bo thoroughly well performed by the Rojal Nary. In common with many others, I hare rcad the rery able paper in the Nineteenth Cealury, written by Sir Garnct Wolseles, and I an one of the few people who do not agree with it in tho least. I think an exarainatiou of it -it has been submitted apparently to no examination in any other periodical-would show that the carcer of that Russian equadron which Sir Garnet Wolseley has painted, has had no parallel in literature, except perhaps the cruize of the "Flying Dutchman." $\mathbf{M r}$ impression is, if they were to pick up some of these small ressets, of the "Frolic" class, for instance, which ho thinks likely, te should be rery much the gainers by the fact, and that they would be terribly hampered by such a capture in their possession.

Captain FrELD, R.N. : I did not come here with any intention of speaking, and I did not hear the opening remarks of the lecturer, but as the Chairman has inrited mo to address the meeting, I will take the liberty of saying a few mords. And, first, I desire to say how gratified I am to sce the howourable gentleman come here as he 
does frequiently, to offer criticisms and remarks and suggest improrements in our estem of naval defence, and I only wish there were more honourablo members in the House of Commons who would take the same interest in naral affairs. It is for want of more men to interest themsclres in naral guestions that the Naral Serrice is not adequately represented nor naral policy adequately discussed in that House. But when I turn to the lecture the honourable gentleman has delirered, I hare to ask mrsclf what practical good is likely to follow from it. He makes certain rery raluable snggestions, but then arises a question, how are they to be carried out? No doubt, as le states; Officers can readily. be supplied by the mother country to our rarious colonies who might assist in any scheme of local defence in those colonies; but, I take it, the motlier country cannot be expected to organize a s5stem of colonial defence in colonial waters. Thaterer defence we may set on foot would be mainly an Imperial defence, and then our best mode of defending our colonies is on the high sens, mecting hostile flects or cruizers. But if the honourable gentleman's riers are to be entertained at all, they must be entertained by the Colonial Gorernments, and it would become our Gorernment's duty to inrite their co-operation and support; therefore, I should say papers like that which has been read to-day hat better be sent forthwith to each Colonial Gorernment, that they may study the question from our point of riem. But tho honourable gentleman suggests that ehips might very well be supplied. IIe did not quite say how thes were to be found, whether to bo built and supplied b5 the Home Gorernment or by the Colonial Gorernments. I ratlicr fancs he inclined to the idea that the Home Gorernment rould supply the slips, and the Colonial Gorernments the men. Then arises this question-the House of Commons is rery jealous of the national expenditure, and if we are to build ships to send out to tiro Colonics for the Colonial Gorernments to man, I think people in Fingland will consider if we build the ships and pay for them, we had better man them ourselres, because then they will not bo confined to the use of a particular colony, but will bo ready for use in any part of the rorld. I, therefore, think the question of the supply of ships by our Ifome Gorernment is one not likely to be entertained by the House of Commons or the country. The scleme sketehed out by the lecturer scems to mo to resolre itself into this, that it can only be used for defensire purposes in their respectircharbours; guarding their harbours, whether by torpedo crews or the erection of forts and manning them; so that the colonial port may be safe from a: coup de main on the part of a foreign squadron. Te hare at present no colonial nary. There is one ehip. I think, in Australia wbich has been gent out and paid for, but I think it would be a rery good thing to invite Colonial Gorcrnments to pay certain sums of mones to meet the expenditure that will be incurred by the Ilome Gorernment if they do send out more ships to colonial waters. If the Colonial Gorernments would be prepared to pay the expenses, the mother country would not hesitate to send more ships out there, and to send ont gunners and crews, and to supplement those crews by men raised in the colonial stations, so that after all it resolres itself simply into a pure question of money. Is there publie spirit cnough in our rarious colonies to carry out the riews the honourable gentleman cnuneintes? I think there is good public spirit in them, but it takes the near approach of war to stir them up to any exertion. It was only the near approach or fear of war that led to the formation of our great Toluntecr Corps in this country, and it will only be the sense of danger which will induce our colonial friends to stir themselres up to form some such corps, whether land or sea forees. But I think they might rers properly be invited by this Goremment to take some measures for their om defence, and not to leare the mother country to do ererything for them. They hare behared admirably in Camada in forming local militia corps, and Australia is stirring itself on the question. They have imvited an eminent engincer to go and make suggestions as to the best waj of defending their harbours. Bejond that, I do not think the mother country can be expected to find funds to protect colonies merely in colonial waters. Whaterer funds the House of Commons mill rote they will insist slall be expended for Imperial defence generally, and not in sending out ships built in this country to be manned by any colonial force whaterer. Those are my humble opinions. I think, whatever can be done by the colonics in the way of local defence will be done on intimation from the mother country, but thes must find the money; they must also find the men, and if thos will find the money for the ships we can readily supply them. 
Captain P. II. Cozoyn, R N. : After Mr. Brassoy's splendid peroration it is ratleer difficult to get one's mind back to the facts of the caso before us, but the remarks of Captain Bridge and Captain Field hare brought us into a more proper frame of mind for discussing the question. At the outset I hare to make ono little remark of a personal nature. AIy brother and I, as in the case of the trins in the popular song, get sometimes mired, and it is diffeult to say occasionalls which is which. Mr. Brassey has sometimes particularized me, and when he has dono solic has always most correctls stated $\mathrm{ms}$ riews, but in the case of proposing to close tho dockyard at Pembroke, and to open a dockjard instead at the Antipodes he is quoting the other twin, and consequently I am not to be held responsibla for that. I do not mean to eay if I considered the question, I should not agree with him; my brother and I are in rery close agreement on these questions, but it is a matter which $I$ hare not at all considered, and I hare no opinion about it. Whererer Mr. Brassey comes I obserro that he brings with him an enormous number of those things which I always express mysclf as being very fond of, namely, facts. He has giren us splendid facts in the paper, as in erergthing he has written on sea matters : the collection of facts is magnificent. Flis statement of the growth of the colovies, I am quite sure, puts a new face upon these questions to most of our minds; for my own part, though I lare bcen considering this question to a certain crtent, I nerer thought before of the enormous growth which has taken place since 1815. It nerer struck me in that light, but it shows mo lare in that time altered our position altogether in the rorld, that whereas we were then a country contained in tho British Islands, with somo littlo outlying dependencies, tre hare now become simply the centre of a great Englishspeaking Empire. I wns rery near bringing a book with me, and I am glad I did not, because if I hacl I should have been tempted to hare quoted from it too largely-a book which my brother has drawn up, which is a simple collection of articles from colonial nerspapers on this question of Imperial defence, and it is something quits surprising to anybody who will run his eje orer those articles to seo how ready the colonies are to nect us if me will only go to work to mect them. They seem to say, "You hare only to say the word; let us talk it orer; admit that jou will not gire us " up; admit that me are brothers; admit that the English Empire is not the British "Islands, but is scattered all orer the world, and we on our side will stand by jou "shoulder to shoulder as long as you choose to call upon us." That seems to be the gencral tone of the colonial press, and that seems to mo to answer Captain Field's question; and $I$ am rers sure of this fact, that erery frienilly word uttered towards the colonies in any publie assembly in Fngland penetrates to the colonies, and is read there, and produces a corresponding friendly fecling towards the mother country, and I am quite certain that that will be the effect of Mr. Brassey's paper here to-day. I recollect reading in some of the debates-in the Xer South Wales Ilouse of Parliament I thint, but I am not sure where-a rery strong opinion mas expressed in farour of trusting to the Royal Nary, and if necessary paying it, for the outer line of defence of their colonies. They seemed to say that they would wish themselres to confine their own efforts, out of the control of the Imperial Gorernment, to the local defenee, but thes did not seem at all indisposed to bear charges for a force which should not be colonial, but should be used for the defence of their colons, as well as of any other, of courso bearing a proportion according to the number of $\mathrm{Irer}$ Majesty's ships which were present. I hope Mlr. Brassey in his answer will make clear the question that Captain Field referred to. I did not mjself gather that he meant this : that England was to build the ships, and that the colonies were to find the men. I rather gathered that he wished that a Rojal Commission, drarn from England and the colonies, should meet together for the discussion of the questionamongst others - of defence; that that would be really a detail to be decided afterwards. So coon as any colony had expressed its willingness to contribute its quota, that then the disposition of that quota, and how the mones was to be spent, would be decided by a joint Royal Commission. That was what I understood. If it were to be eaid that an ironclad was to be built by Eugland, and sent out to a colons, to lio there in the harbour to be only manned in time of war, I think I should be rather against that polics. I should rather sas that a colony like Australia should proride a quota for the purpose of kecping up a sufficient Imperial naral force for the outward defence, and that then the local arrangements of the colonies themselres should 
bo cntirely deroted to the defence of their harboury against blockade or sudden attacks. MIr. Brassey has rery truly represented me in saying I put great faith in a colonial system of naral rolunteers, who shall rest the defence of their ports mainly on the use of torpedoes. It is the cheapest mode of defence, especially the spartorpedo-Mr. Thornjeroft's model. It is cheap, and it requires for its use men of great intelligence. Tho class from which the rolunteers would be drawn would be the people to manage such resscls: they rould hare the necessary resolution and daring to make the attack, and, at any rate, if they did nothing else, I belicro they mould keep them off by simple fear. But when they had done that, they would leare the Imperial naral force frec. Wo should always know the ports were safo behind us, and we should take care that ships bound to those ports were unmolested on their way towards them. But I should not draw the line so closely as to torpedoes; I would extend it, I think, to the "Gamma" and "Staunch" class of gunboat, a class of ship quite capable of attacking an ironclad, but not capable of keeping the sca, and which seems to be a weapon costing a small sum, and exceedingly arailable for the defence of ports. I was rery much struck with AIr. Brassog's statement of the number of eca-faring men arailable on the const of Canada and Newfoundland, and with the facilities which aro giren for the drill of those mon at small inconrenience to themselres on account of the long minter. I cannot help thinking if they, as a small branch of the great matter, were taken in hand, we might be able on occasion to drawn on Canada if we wanted it, for I should not be prepared to go to Australia for our seamen. I think the diffeulty of the question is this: that up to quite recent years the colonies hare been told by us alwajs that, "In point of fact, we do not much care about you, for jou can go if you like. You " are of no rery great serrice to us : we can get on very well without jou. If you " gire us trouble, we shall $\varepsilon a 5$, "Go." "It has been the poliey of the country for a certain time. That policy, I an quite certain, is rerersed, and I hopo will nerer como forward again. I am quite suro as long as the English-speaking nations spread orer the face of the carth hold together, it will be impossible for anybody clse to make head against us.

Colonel IIExns Cirstox: The speech which has been made by Captain Colomb is execedingly raluable on many points, especially regarding our conciliatory treatment of the colonies at the present time. If the prorinces of North America had been met with such considerate treatment at the time when they rere talking of separating from us, they would probably nerer hare separated themselves from England. Then I hare to say it is a great mistake to suppose that mo can do anything in war if we do not get rid of the Declaration of Paris. There has been a discussion on that subject already in this Institution, and it is therefore unnecescary for mo to say anything more; but I am firmly conrinced that unless the Declaration of Paris is witluctram, we can nerer do anjthing in war. There is a rery speedy method of putting an end to war by sea altogether, if the English choose to make use of it. The fact is simply this, if jou will hare the goodness to stop the making of large guns for other nations by our omn people, if you will put $a$ stop to making torpedocs by our own people, and then wam other nations that no ship will be allowed to leare their ports with a greater thickness of iron or guns of more than a certain size, then all naral mar would ccase, and a sufficient number of ironclad ran-gunboats would maintain the freedom of all the seas for the benefit of the commerce alite of all nations.

Captain ScorT, R.N.: Captain Bridge has touched upon a point which is no doubt rery important-that is the suceess of the "Alabama" during the American TVar. We must, howerer, remember in regard to the United States losiug their trade, that at that time aniling ships were becoming obsolete, and their tracie from being principally carricd in such ressels was also going domn the incline; hence, it only needed a slight push, riz., the additional war insurance, to make the Americans sell their ressels, and their trade to pass with the ships sold to neutrals. This, thercfore, is not a parallel case to ours at the present time. With respect to Mr. Brisser's rery able paper, I rish again to refer to a point that has been more than once brought formard in this Institution. It is not enough to get weapons stored in readiness, but you must hare them put into their right place for uso in order to bo prepared for mar. To get guns ready to be put on board ship when war breaks out; 
is not the way to be prepared for a sudden outbreak of hostilitics. Tre hare long been training and at a considerable cost our Reserre seamen: these men aro con. sequently always learning, but for want of practice are, I fear, nerer getting perfect. What the sailors want is, that when thes go on board their omn merchant ressels they should carry out what they hare been taught. Eaeh merchant ressel should, I think, be armed so as to bo in herself formidable. Such a ressel, if commanded by a Reserre Captrin, and manned in part "by Reserre men who had been keeping up their drill, would be far more formidable than any priratecr that could be hastily fitted out to attack her. It should be remembered that these merchant ressels would be handled by men second to nono in shill; in fact, many of their Captains are first-rate fellorrs, and I need not point out to you that their ships carry a splendid reapon which is ready at all times, riz.,.a straight, porrerful, knifeedge iron stem. To wooden ressel struck by such a renpon would hare any chance of escape. Giren an iron merchant ressel going at enormons specd, and with a powerful stem, and you only want to add two or three light guns-not 64 or 32 pounders which Nould orerstrain her, but 12-pounders; and she would then obtain the character of an armed ressel, and thus gire the men confirlence in protecting themselres. Besides the light gun and the linife stem there is the spar torpedo, a weapon which our Reserre seamen can casily handle; and as most of our merchant steamers carry whale boats they could be at onee prorided with an additional means of eflicient defence. Then, as to Canada, the merchant ships belonging to that country-manned by their splendid scamen-would be really. a very powerful supplement to our force of regular men-of-war if proper arrangements were mado in time of pacc. Tre hare now got into a habit of considering the ironclad only as a man-of-war, but theso merchant ressels are, at least for all point of defence, equal to most of our rooden ressels in their speed, in their power of ramming, in their sustained steaming, and in their eca-beeping porrers. Turning to what Mr. Brosscy has said about the armament for our colonics, I think it is necessary to commenee on a small scalo of expenditure, and that wlat is most ranted is first to enrol the scafaring men that are on their coasts for coast defence; likewise to enrol all the traders and their scamen as a naral Reserre, and not to incur the expense of building special war resscls, but rather to utilise all cristing means of defence: Let the men be enrolled and also the ressels and boats in rhich thicy are aceustomed to go to sea, and then what moro simple than to drill and afterwards to put torpedoes on board them? In addition to the torpedo armament, which I look upon as mainly scrriceable for the purposes of defence, you have in jour colonics an encrgetic seafaring people that could be easily organized for defence; and $I$.believe it could be done at a rery small cost. Ify own idea is, that from the instant the Reserre men are called out for drill thes shonld be taken to practical work; let them be put to fortify those positions which are most important, and to make roads to and from them along the coast line. There are no fortifications so cheap or more eflicient than sand banks and earthworks. Therefore, your shoro drill should commence with erecting such defences, and your naral drill with firing torpedoes, which should bo kept at all times ready for use. The colonists, ns wo hear on all sides, are quite ready to do their part, and I do beliere that if that part mere pointed out by a Rojal Commission, it would hare most important results. It would certainly show to other nationalities the latent forco and power which"this country really possesses. We hare seen some newspaper articles lately which tend to give foreigners a rery imperfect notion of the actual resources of this country; these affirm that our Empire is so scattered that it has an inherent source of reakness. I renture to maintain, on the contrury, that its extension is an inherent source of strength, for our colonics, scttlements, and coaling stations now girdle the carth, and would enable us to kcep tho seas in time of war. I again affirm that all our ironelads should be sea-going, and that a coast defence ironclad is an anomaly; and I beliero that this paper is likely to be of rery great service, and I for one think that our hearty thanks are due to Mr. Brassey for coming formard and reading it on the prescnt occasion.

Major-General Lowax : I beg, as a military man, to express my liumisle but rarm apprecintion of the opportune and admirable paper which has beck brought with so much pains before us to-day by Mr. Brasseg. I rejoice to know that he is 
a Mrmber of Parliament, and I trust that many Members of Parliament will be in. oculated with the same idens, and that the rerg forcible suggestion which he his put before us of a Rojal Commission being appointed to inquire into this matter, and so bring it to bear upon our colonies that a system of defence by naval yoluntecrs may be adopted; they will at once strengthen the hnnds of the mother country and the colonies, and which will be a source of gratification to both. I can, from many Jears spent in Canada, fulls confirm what Jou, Sir, hare said and what Captain Colomb lias brought out as to the warmth of the fecling which exists in those colonies tomards us, especially in that great dependency of ours of British North America. There are no warmer hearts towards Britain tlan beat there, and it only requires this country to speak to them and to put forward somo system which will draw out their wealth of men and mones to enable that countrs to do much more than slee is at present doing for her own defence. We must all feel it, and those especially who hare been inuch in the colonies, that they are not only the peculiar glors, but that they will be the great living strength of this great country; and the more we keep warmly towards them, and the more we derelop their lore and feeling, the more in the end they will respond to us and becomo our outlying towers of strength. At this timo we are reading in the papers day by day of a threatencd Fenian attack on Canada, and I think some gunboats are being placed on the lakes. I hare lind no connection for some ferr Jears with Canada, and I do not know whether crens from our men-of-war at Quebec and Ialifax have been furnished for these gunboats, but it certainly mould be $n$ most desirable thing if there were almajs present on the minor lakes of Canada, gunboats thoroughly manned by our Canadian comrades. It is a matter comparatirely unimportant whether oflicered wholly or partially by our colonists. That would be casily settled by a Rogal Commission; but that gunboats in a stato of thorough readiness and efficiency should be there, that the spirit of our Rojal Nary burning in the bosoms of these Canadians should be rightly guided, is a matter of tho greatest importance, and for the wholo of Canade it is most desirnble that some system of naral volunteers should be adopted. I do trust that all that all of us can do, will be done to press forward the matter of a Rojal Commission being appointed. Beliering it of greatest moment to the future of tho country that some system for the defence of our grent Colonial Empiro should be adopted, and that soon, I for owe heartily thank you for the admirablo paper you haro read.

Lord AlreEd CnURCHIL: I entirely concur in the obserrations of Mr. Brassey as to the necessity for a Royal Commission composed of representatircs of rarious colonics bcing appointed for the purpose of investigating this question, and putting it on a proper basis. The obserrations I wish to make apply more especially to the dustralian colonies. There are sereral colonies within a group, at present some. what sparsely peopled, and there may be somo difliculty in organizing for them a sufficient naral force. Ifowerer, I think that at present their first endearour should be in the formation of carthworks at the entrance to the harbours. Most of their harbours are casily defended by means of artillery and torpedoes, and at present there is, I think, one ironclad there, the property of Tictoria. I should hope in time we may see, if this question derelops itself further, a colonial fleet of ironclads for that especial group; but I think for that purpose the colonies should federato themselres. At present they are all entirely separated one from another, having no sort of control one orer auother, and it would be necessary therefore for the Home Gorernment to organize a confederation scheme for defence which should be submitted to the colonies and receire their assent. In that case jou might arrire at somo principlo by which thes should contribute to the fornation of an ironclad flect for coast purposes, and at the same time as to mlat amount or proportion of eapport or assistance should be rendered by the Rojal Nary. But in order to do this, I should like to understand what is the nature of the MIuting ict under which they can serre. Tould a naral rolunteer serre under the BIuting det of the Imperial Gorernment, or hare they a Mutiny Act of their own? It may be necessary, in order to carry out $m$ scheme, that the Imperial Gorernment should themselres pass a Mutiny Act applicable to the whole of that group. The same principle mould apply to other colonies in other parts. I think that is a question which no doubt will come under the consideration of this Royal Commission. That we ought to do now is to 
urge, as a commencement, the appointment of a Royal Commission for the purpose of corrmencing and inrestigating this thing. And the Imperial Gorernment should themselres take the initiatire in this. Fou cannot expect the colonies to do it for themselves. It is the duty of the Home Gorernment to take the initiatire. I cannot conclude without expressing my own thanks for the admirable paper Mr. Brassey has just read to us: it is not the only occasion on which wo haro felt deeply in. debted to DIr. Brasses for his exertions in this direction.

IIajor BAYLIs, Q.O.: I lare attended many lectures at this Institution, but there hare been none in which $I$ hare taken a more warm and deep interest thon the present. It has giren me, and I am sure those who are here present, great pleasure to be here and to have heard the able paper read by Mrr. Brasser. There has been much good done in this Institution by the lectures and by papers rend here; they hare been read in this small room, but the bennfit has extended far and near. I think it may also be said of Mrr. Brasser's paper that the good which has been done by reading tho paper here will be extended far and wide. And it will hare this adrantage to us, because the good attaches to those who are bound to us, namely, our colonies. I beliore the dependencics of England, when they read this paper, as cmanating from the United Serrice Institution, will see that we are alive to the erils in which war may inrolre them. It is a serious matter, no doubt, for our colonies to fecl and know that, when our statesmen think war may bo necessary, they too may themselres be inrolred in war, but they will be glad to learn that this country is also sensitive to its duties, and will do erersthing to aid them in case of war. I know nothing that will do so much good as the paper which has been read to-day, for we know the ralue of the self-dependence which it inculeates, at the same time it shows that we care for their interests. I do not beliere the colonies wish that England should gire them all and crers assistance, but what they want is to know what England expects of them, and what England mill suggest to them to do for themselres, in addition to aid from the mother country. Well, now that paper sug. gested that thes should, on their part, put their own house in ordex-that they should look to sclf-defence and sclf-reliance; and although, if England be inrolred in war, we might not look to our colonies and dependencies to defond us, they will, I beliere, if necessary, Canada and all the countries connected with dear old England, always stand by her, and I was delighted to hear-unmistakably from those hearty cheersto-day that dear old England wishes to stand by her colonies, although it has been suggested by one that England rished to be disunited from her colonies. I am sure when thes fecl that we are on the right course now, that we are endearouring to suggest to them the best means by which they may be prepared in case of war, they will thank us for this paper, and I hare no doubt that these raluable suggestions will lead to rery much grcater results. I cannot help thinking myself, in my own humble was, it will lead to a communication between the heads of the Gorernment here and the authoritics in our colonies, by which thes will put their heads together to bring about the best means of rendering effeient defence to the colonics, who will suffer in case of war with England. I do not think it stops there, for I beliere the colonies will do their best also to assist Fngland. There is one thing which has reliered my mind considerably, and that is with rcgard to the "Alabama." We are rerr glad to hear that that is not $n$ parallel case, and that what happened in the case of the "Alabama" is not possible with us now, and that England is not likely to suffer so much as the Americans suffered, or at all, from these lostile cruizers. This is a great relief to my mind, and I think we hare heard rers gond reasons for it. Our resscls are mostly steamers, and can, therefore, take care of themsclres better than was the case with the sailing ressels of the Americans, which fell a prey to the ateamers.

Captain IIULx, R.N., Hydrograplic Department: With referenco to tho remarks made by Captain Bridge, I mas tell him his hopes, with regard to the natire sailors of India, hare already been, in eome respects, realized. I allude to the rork now going on under the Indian Marine Surrey Department, and, though it mas be said that such labours are rather in the serriee of peace than of war, still, as the old Napoleon managed to conquer Europe by haring good maps and knoming how to use them, so (and here $I$ am sure all sailors will agree with me) success in $\mathrm{a}$ future naral war will, on the same grounds, greatly depend on our Captains haring good 
charts and knowing bow to use them; therefore, I can say the native sailor of India has already done good work in the defence of that Empire, for when, through the cnergy of Mr. Clements Mrarkham and Captain Tajlor, the Indian Surrey was established in 1875, although the Officers were supplied by the Admiralty, the men were found in India. Captain Tajlor's staff has already surrejed Moulmein, Rangoon, Chittagong, Falso Point, Coringa, and Madras. One party is now working in Palk Strait, while Narigating Lieutenant Jarrad and another party are surrering the west coast of Ilindostan, to the south of Bombay, the whole of that important part of a surrey, the soundings, being taken by natire sailors.

IIr. BRISSEY, in reply, said: I am very much obliged to those Oficers who hare spoken, for the too kind manncr in which they hare referred to my paper. I was much flattered by the invitation I received from the Council of this Institution inriting me to prepare a paper on the Colonial Naral Reserve; and if what I have written has any effect in sctting in motion a scheme for organizing our resourecs for colonial self-defence, I shall feel thankful that I hare becu engaged in such a useful takk. The point has been referred to by sereral speakers as to the mode in which the expenditure necessary in carrying out such a scheme was to be dealt with. Captain Field rery truly said, after all this is a matter which camnot be undertaken without an expenditure of moncy; and speaking as a member of the Legislature, $I$ fully appreciate that aspect of the case, and consider that it will require rery delicate handling to settle it satisfactorily. Now the foundation of a practical scheme must be, as I lare cndearoured to point out, an inquiry by some competent and fully representatire bods, and I cannot conccire how a more effectiro mode of inquiry could be derised than that which rould be prorided by a Rojal Commission. As crersbody has said, the initiatire must be taken by the mother country, and the best mode by which the mother country con point out what is required to bo done, and bring home to the appreciation of the colonists the necessity for doing what is necessary, will be provided by giring them the full report on the subject from a Royal Commission composed of naral and military authorities and representatires of the colonists, who would be able to speak on belialf of the Colonial Gorernment as to the ability and willingness of the taxpajers in those colonies to contribute their share. I do not think one can speak definitely on this point until we hare had this casential preliminars investigntion. No doubt the Commission rould begin, as indiriclual writers on this eubject hare begun, by lajing down what are the important and strategical points which jou have to defend. Some of these strategical points being coaling stations, necessary bases for naral operations, would be ports of rery flourishing trade. We may fairly look, in such a case as that, to the mercantile community to contribute what is necessary. In other cases jou haro an important strategic point which has not a flourishing trade, which is important in a naral point of riew, but not in a commercial point of view; such, for instance, as the Falkland Islands, or perhaps Vancourcr. You could not reasonably expect, in such a case as that, that the expense would be met from any other souree than the national exchequer. Gibraltar and Mralta are important strategical points and defended, and I think rery properly so, at the expense of the mother country. I now turn to the question rery properls raiscd by Captrin Field with reference to the ships. Those ships which may be considered necessary for the local defence of a flourishing commercial colony would, I think, belong to and be paid for by the colonics: Those ships which jou might think it necessary to build for the local defence of places like tho Falkland Islands mould nccessarily be paid for by the Home Gorernment. Fach caso would hare to be dealt with with reference to its local and special circumstances, which would be no doubt properly appreciated by the Rojal Commission. I am glad that what I hare said with reference to Canada and Nerfoundland has becn approred bj those naral gentlemen rho hare spoken. In Canada there is a most admirable field for the organization of a naval reserve. There is a large sea-faring population, hardy and logal, and raluable in erery way for naral purposes, and from the necessity of the caso unemplojed during a considerable portion of the Jear. Aud when rre come to consider how near the shores of Canada and Newfoundland are to this country, the facilitics for communication by telegraph, the means you hare of bringing to this country, if required, a rery considerable force, so that in a fortnight from the timo when your appreciation of the necessity had been formed, Jou might hare jour FOL. XXII. $2 \mathbf{Y}$ 
Canadinn reserres in your home ports, ready to man your ships; when you come, I an; to consider all these things, it must be achorledged that we hare too long neglected a rery valuable cource of naval power, and one which I trust will be dereboped by such an organization as the Admiralty with rery'small expenoe might rery oxsily establish on those coasts. I am glad to be reminded by my friond Captaj Bridge of the resonrces we have in Indin.. India I look upon as a precious jewel in the national diadem, but it inrolres the country in immenee responsibilities. I will not enter into the question now, but the day may come when it maj be to some extent a finmeial burden to this conntry. In any case it is satisfactory to know that we not only have responsibilities and burdens to bear in eonnection with -Indis, but that we derive sourees of etrength from our Indian connection. I was glad to hear from the obserrations which fell from Captain Colomb that there has been an expression of opinion offeially and in Parlianent in the colony of New South Wales 6o the effect that the colouy would be willing to contribute its proportion to the main. Senance of such ressels of the Rojal Nary as might be permanently stationed in the colonial waters. I thinls we might reasounbly expect such a riew to be entertained in a wealthy and increasing colonf. I cannot answer the questions which hare been raized about the Ifutiny Act as a lawser, for although called to the Bar, I have nerer practized in the profession.

I thank you very much, and can only say, as I have already observed, it has been a work of great satisfaction to me to hare been called upon to prepare this paper; and if it does tend to set a morement on foot which will be of practical ralue; $I$ shall hare been very proud to hare taken some part in the matter. With reference to Parliament you must all sppreciate this -it is rery diffeult to rouse the attention of Parliament to new subjects. In such a case as the one which we are discussing, an expression of opinion by the members of the United Serrice Institution is of great ralue as an initiatory step before bringing any proposals relating to a Colonial Naral Reserre before Porliament and the country.

The Chirmarax: Before I ask you to rote, as I am sure you will with acclama. tion, your thanks to Mr. Brassey for his tery able paper, I would remind you that he possesses peculiar qualifications for speaking to us on this subject. In the firet place he commands the bods of Naral Artillery Volunteers in England, and he has just becn round the world, where he has just risited our colonies and has seen how necessary it is that this step should be carricd out. I met him at Hong Kong, a colony in which there is no rolunteer force. Hong Kong is a most important British colony, and yct a man might walk for dass about it without finding a fort. It is absolutely undefended, exeept by a few insignificant gnns. Singapore is also aboolutely undefended. Wo hare in the China and Japen Seas not exactly colonics, but settlements very much of the nature of colonies, riz., settlements on the main land in the treaty ports. It is rery difficult to persuade the English inhabitants to more in this matter of creating a roluntecr force. Englishmen in those distant parts may fight well enough when driven into a corncr, but they for sarious reasons will rarely combine together to form rolunteer forces and submit to drill. You may find at one port some one or more enthusiasts who take the question up, and I do not know what we slould do without our enthusiasts, as they form a nucleus. Thus we have, as at Shanglai, a very respectable voluntecr infantry force--there is a small foree of caralry and Gatling gans-rery mach the kind of force that $\mathbf{M r}$. Brassey las - spoken of, that is what we want in all our colonics, as I understand from his paper; and I entircly agrce with bim. The only difficulty is to start them. I seo no rcason why the Act authorizing the enrolment of roluntecrs should not bo crtended to the colonies and to the treaty ports of China and Japan, and that promptly. Wo are bonoured to-dlay by the presenee of some ladies. Depend upon it that thero is a great deal in the power of the ladics in this question. I apesk quite seriously. If the ladies in the colonies and settlements referred to would lool shyly on any young men who were not enrolled in a corps of roluntecrs for the defence of the ladies themselres, and of the British interests, then I beliere we Bhould find all our colonies and all our outlying settlements thoroughly well defended. I hare rerg muel pleasure in returning our thanks to Mr. Brassey for his rery able 3octure. 